\title{
STUDI OPTIMASI EKSTRAKSI KANDUNGAN SENYAWA FENOLIK TOTAL DAN UJI AKTIVITAS ANTIOKSIDAN DARI DAUN MANGGIS (Garcinia mangostana Linn.)
}

\author{
Emil Salim ${ }^{1, *}$, Yogi Afritunando ${ }^{2}$, Nindi Antika Febriana ${ }^{1}$, Mai Efdi ${ }^{1}$ \\ ${ }^{1}$ Laboratorium Kimia Organik Bahan Alam, Jurusan Kimia FMIPA Universitas Andalas \\ ${ }^{2}$ Laboratorium Kimia Lingkungan, Jurusan Kimia FMIPA Universitas Andalas
}

\author{
Corresponding Author: \\ Emil Salim \\ emilsalim@sci.unand.ac.id \\ Received: October 2018 \\ Accepted: March 2019 \\ Published: March 2019 \\ Publishing services provided \\ by Open Journal Systems \\ (c) Emil Salim et al. This is an \\ open-access article \\ distributed under the terms \\ of the Creative Commons \\ Attribution License, which \\ permits unrestricted use, \\ distribution, and \\ reproduction in any \\ medium, provided the \\ original author and source \\ are credited.
}

\begin{abstract}
This study aims to determine antioxidant activity and total phenolic content of mangosteen leaves in several different solvents. The antioxidant activity test of the extract was determined by the DPPH method and the total phenolic content was determined by the Folin-Ciocalteu method. The phytochemical test of mangosteen leaves showed the presence of phenolic compounds, saponins, triterpenoids and alkaloids. The extraction results increase with increasing water content in methanol, ethanol and acetone. The highest amount of extract was obtained using 50\% acetone solvent $(34.98 \pm 0.17 \%)$. Extraction using $100 \%$ ethanol showed the highest total phenolic content $(614.25 \pm 5.58 \mathrm{mg}$ GAE / g extract $)$ and the lowest IC 50 value (5.81 mg / L). The results of this study indicate that the use of 50\% acetone solvent can optimize the amount of extract and $100 \%$ ethanol can optimize the content of total phenolic compounds and antioxidant activity of mangosteen leaves.
\end{abstract}

Keywords: Garcinia mangostana Linn., Solvent extraction, Total phenolic content, Antioxidant

\section{PENDAHULUAN}

Manggis (Garcinia mangostana Linn.) adalah tumbuhan tropis yang tersebar di Indonesia, India, Myanmar, Malaysia, Filipina, Sri Langka dan Thailand. Manggis dikenal sebagai ratu buah karena rasa buahnya yang manis dan lezat. Pada umumnya, masyarakat mengenal tumbuhan manggis untuk memanfaatkan buahnya saja. Padahal bagian lain dari buah manggis juga bermanfaat, seperti kulit buah manggis dimanfaatkan sebagai bahan pewarna alami dan bahan baku obat-obatan. Kulit buah manggis sudah digunakan sebagai obat tradisionla di Asia Tenggara untuk mengobati infeksi kulit, inflamasi, cholera dan disentri ${ }^{[1]}$.

Kandungan metabolit sekunder dalam isi buah manggis yang berwarna putih diantaranya yaitu triterpen, mangostin, tanin, dan resin.
Sedangkan yang terdapat dalam kulit buah manggis yaitu antosianin dan xanthone. Dari bagian kulit buahnya, baik yang masih muda maupun tua, mengandung senyawa xanthon yang mempunyai aktivitas sebagai antioksidan. Senyawa xanthon ini terdapat pada genus Garcinia [2]. Hasil penelitian sebelumnya menunjukan ekstrak kulit buah manggis memiliki aktivitas antioksidan yang kuat dibuktikan pada semua fraksi pelarut baik fraksi metanol IC50 8,00 mg/L, IC50 etanol 9,26 $\mathrm{mg} / \mathrm{L}, \mathrm{IC}_{50}$ etil asetat $29,48 \mathrm{mg} / \mathrm{L}, \mathrm{IC}_{50}$ tersebut kurang dari $50 \mathrm{mg} / \mathrm{L}$ dan aktivitasnya lebih besar jika dibandingkan dengan aktivitas antioksi dan control positif BHT dengan IC $_{50}$ $60,82 \mathrm{mg} / \mathrm{L}{ }^{[3]}$. Penelitian lainnya yaitu uji aktivitas antioksidan ekstrak daun manggis dengan metode DPPH. Ekstrak etanol daun manggis berpotensi sebagai senyawa antioksidan alami karena memiliki aktivitas 
antioksidan terhadap radikal bebas DPPH dan ekstrak etanol memiliki daya antioksidan lebih rendah 11 kali dari vitamin E sampel [4].

Penelitian ini mengembangkan potensi bagian daun tanaman manggis dengan cara maserasi untuk mengetahui aktivitas antioksidan dari ekstrak daun manggis dengan pelarut air, metanol, etanol, dan aseton. Penggunaan pelarut ini bertujuan untuk mengetahui pelarut yang paling efektif untuk mengekstrak senyawa fenolik dan aktivitas antioksidan yang aktivitasnya diperoleh dari pengukuran serapan dengan spektrofotometri UV-Vis. Dalam penelitian ini, pengujian kandungan senyawa fenolik total menggunakan metode Folin-Ciocalteu dan uji aktivitas antioksidan menggunakan metode DPPH. Metode ini cukup sederhana dan mudah dikerjakan.

\section{METODOLOGI PENELITIAN}

\section{Bahan Kimia}

Daun manggis, akuades, pelarut (metanol, etanol, aseton) yang dibeli dari MERCK, pereaksi Mayer, pereaksi Liebermann-Burchad, sianidin test, besi (III) klorida, ammonia, natrium hidroksida, DPPH (2,2-difenil-1pikrilhidrazil), asam askorbat sebagai control positif pada uji antioksidan, natrium karbonat $20 \%$, reagen Folin-Ciocalteu, asam galat sebagai larutan standar pada uji antioksidan.

\section{Peralatan}

Gerinda, neraca analitik, ayakan 0,25 $\mu \mathrm{m}$, magnetic stirrer, sentrifus, rotary evaporator BUCHI R-124, freze drying, tabung reaksi, chamber, pipa kapiler, lampu UV (254 nm dan $356 \mathrm{~nm}$ ), botol vial, spektrofotometer UV-Vis Thermo Scientific, dan alat-alat gelas.

\section{Persiapan sampel}

Sampel daun manggis sebanyak 1000 gram dipotong kecil-kecil, dibersihkan dan dikeringanginkan selama lebih kurang 2 minggu pada tempat yang tidak terkena cahaya matahari langsung. Setelah kering sampel tersebut kemudian dihaluskan menggunakan grinder dan di ayak menggunakan ayakan 0,25 $\mu \mathrm{m}$ untuk mendapatkan serbuk. Sampel kemudian dicuci dengan menggunakan pelarut n-heksan untuk menghilangkan lemak.

\section{Pengujian profil fitokimia sampel daun manggis}

Pengujian profil fitokimia yang dilakukan mengacu pada prosedur kerja yang dilakukan oleh Nursal [5] yang merujuk pada metode Harborne (1987) [6]. Serbuk daun manggis sebanyak 2 gram dimasukkan ke dalam tabung reaksi, kemudian ditambahkan metanol dan dipanaskan dengan spiritus selama 5 menit. Larutan tersebut diambil untuk pemeriksaan senyawa flavonoid, fenolik, saponin, triterpenoid, steroid, alkaloid dan kumarin.

\section{Pemeriksaan flavonoid (Sianidin Test)}

Sebanyak $2 \mathrm{~mL}$ larutan ekstrak metanol dimasukkan kedalam tabung reaksi, ditambahkan asam klorida pekat dan sedikit serbuk magnesium, terbentuknya warna jingga sampai merah menunjukkan adanya flavonoid [7].

\section{Pemeriksaan fenolik}

Sebanyak $2 \mathrm{~mL}$ larutan ekstrak metanol dimasukkan ke dalam tabung reaksi, ditambah larutan besi (III) klorida dan diamati perubahan warna larutan. Apabila larutan bewarna biru atau hitam menandakan positif mengandung senyawa fenolik ${ }^{[7]}$.

\section{Pemeriksaan saponin}

Sebanyak $2 \mathrm{~mL}$ larutan ekstrak metanol dimasukkan kedalam tabung reaksi dan dikocok. Apabila terbentuknya busa yang tidak hilang ( \pm 5 menit) setelah penambahan beberapa tetes asam klorida pekat, menunjukkan adanya senyawa saponin ${ }^{[8]}$.

Pemeriksaan triterpenoid dan steroid (Pereaksi Liebermann-Buchard)

Sebanyak $2 \mathrm{~mL}$ larutan ekstrak metanol ditambahkan $2 \mathrm{~mL}$ akuades, kemudian ditambahkan $2 \mathrm{~mL}$ kloroform, terbentuk 2 lapisan dan diambil lapisan kloroform menggunakan pipet tetes dan diteteskan pada lubang pelat tetes, ditambah asam sulfat pekat dan anhidrida asetat. Apabila larutan bewarna ungu-merah menunjukkan adanya terpenoid 
dan apabila terbentuk warna hijau-biru menandakan adanya steroid [7].

\section{Pemeriksaan alkaloid}

Sebanyak $2 \mathrm{~mL}$ larutan ekstrak metanol dimasukkan kedalam tabung reaksi dan diuapkan pelarut metanol, residu yang terbentuk dilarutkandengan $5 \mathrm{~mL} \mathrm{HCl} 2 \mathrm{~N}$, kemudian ditambahkan dengan pereaksi Mayer.Positif alkaloid jika menghasilkan endapan putih ${ }^{[8]}$.

\section{Pemeriksaan kumarin}

Ekstrak metanol ditotolkan pada pelat KLT menggunakan pipa kapiler dan dielusi dengan etil asetat: metanol (9:1) di dalam chamber. Plat KLT yang telah dielusi diamati dibawah sinar UV $\lambda 365 \mathrm{~nm}$ dan $254 \mathrm{~nm}$ terlihat adanya warna berfluorisensi, warna biru tersebut bertambah terang biru setelah disemprot dengan basa maka hal tersebut menandakan adanya senyawa kumarin ${ }^{[8]}$.

\section{Ekstraksi Sampel Daun Manggis}

Pelarut yang digunakan pada penelitian ini yaitu pelarut air, metanol, etanol, aseton dan pelarut air dengan perbandingan konsentrasi yang berbeda terhadap metanol, etanol, dan aseton (50\% dan $75 \%)$. Sampel berupa serbuk halus $( \pm 1,0000 \mathrm{~g})$ diekstraksi dengan metode maserasi dengan bantuan magnetic stirrer selama 30 menit menggunakan pelarut sebanyak $20 \mathrm{~mL}$. Kemudian di sentrifus dengan kecepatan $3000 \mathrm{rpm}$ selama 20 menit. Supernatan dan residu dipisahkan sehingga didapatkan maserat dari masing-masing pelarut. Setiap maserat yang diperoleh diuapkan pelarutnya dengan rotary evaporator pada suhu $40^{\circ} \mathrm{C}$, kemudian didapatkan ekstrak pekat dan ditimbang. Untuk pelarut yang mengandung air dikeringkan menggunakan freze drying. Ekstrak kering dari masing-masing pelarut dilakukan uji penentuan kandungan fenolik total dan aktivitas antioksidan ${ }^{[7,8]}$.

\section{Penentuan Kandungan Fenolik Total}

Penentuan kandungan fenolik total menggunakan metode Folin-Ciocalteu mengacu pada prosedur kerja yang dilakukan oleh Purnama (2015) dengan beberapa modifikasi [9]. Masing-masing ekstrak ditimbang sebanyak $10 \mathrm{mg}$ dan dilarutkan dalam $10 \mathrm{~mL}$ metanol sehingga didapatkan konsentrasi sebesar $1000 \mathrm{mg} / \mathrm{L}$. Larutan induk $1000 \mathrm{mg} / \mathrm{L}$ diambil sebanyak $1 \mathrm{~mL}$ kemudian diencerkan dengan metanol di dalam labu 10 mL untuk mendapatkan konsentrasi 100 ppm. Sebanyak 0,5 mL dimasukkan kedalam labu ukur $10 \mathrm{~mL}$ dan ditambahkan $0,5 \mathrm{~mL}$ reagen Folin-Ciocalteu. Campuran tersebut didiamkan selama 5 menit kemudian ditambahkan $1 \mathrm{~mL}$ larutan natrium karbonat $20 \%$ dan diencerkan dengan akuades sampai tanda batas. Larutan tersebut didiamkan selama 2 jam dan absorban diukur pada panjang gelombang $765 \mathrm{~nm}$.

Kandungan fenolik total masing-masing larutan uji ditentukan dari persamaan regresi kurva larutan standar asam galat (gallic acid). Kandungan fenolik total dinyatakan dalam Gallic Acid Equivalent (GAE).

\section{Pengujian Aktivitas Antioksidan Ekstrak Daun Manggis}

Uji aktivitas antioksidan menggunakan metode DPPH (2,2-difenil-1-pikrilhidrazil) mengacu pada prosedur kerja yang dilakukan oleh Aranda (2011) dengan beberapa modifikasi [10]. Larutan uji dibuat dengan cara melarutkan 100 mg masing-masing ekstrak dengan metanol dalam labu ukur $100 \mathrm{~mL}$ sehingga didapatkan konsentrasi dari larutan induk sebesar 1000 $\mathrm{mg} / \mathrm{L}$. Selanjutnya dibuat variasi konsentrasi larutan uji yaitu 12,5; 10; 7,5; 5; 2,5 mg/L dari larutan induk yang dimasukkan dalam labu ukur $10 \mathrm{~mL}$ dan ditambahkan metanol sampai tanda batas. Masing-masing variasi konsentrasi dari larutan ekstrak daun manggis dimasukkan kedalam vial sebanyak $2 \mathrm{~mL}$, tambahkan dengan $3 \mathrm{~mL}$ DPPH 0,004\% (b/v). Campuran didiamkan selama 30 menit setelah penambahan DPPH. Larutan dimasukkan kedalam kuvet dan diukur absorban dari masing-masing konsentrasi larutan uji, DPPH (kontrol negatif) dan asam askorbat (kontrol positif) pada panjang gelombang $517 \mathrm{~nm}$.

\section{Uji Statistik}

Percobaan dilakukan tiga kali pengulangan dan semua pengukuran ditentukan dalam triplicate. 
Pengujian data digunakan one-way ANOVA dengan level signifikan $p$-value $<0,05$.

\section{HASIL DAN DISKUSI}

\section{Uji Kandungan Metabolit Sekunder Ekstrak} Daun Manggis

Hasil uji profil fitokimia dilakukan pada ekstrak daun manggis dengan menggunakan pelarut air, metanol, etanol dan aseton dapat dilihat pada Tabel 1. Hasil uji fitokimia ekstrak daun manggis (Tabel 1) menunjukkan bahwa adanya kandungan senyawa metabolit sekunder golongan fenolik, saponin, triterpenoid dan alkaloid dan tidak terdapat senyawa golongan flavonoid, steroid dan kumarin. Senyawa fenolik dan triterpenoid berpotensi sebagai antioksidan [11]. Uji fitokimia yang dilakukan oleh Qamar et al, ekstrak metanol daun manggis mengandung antrakuinon, karbohidrat, terpenoid, saponin, flavonoid, glikosida, tannin dan fenol ${ }^{[12]}$.

Tabel 1. Hasil uji fitokimia ekstrak daun manggis

\begin{tabular}{|c|c|c|c|c|c|}
\hline \multirow{2}{*}{$\begin{array}{c}\text { Kandungan } \\
\text { Metabolit } \\
\text { Sekunder }\end{array}$} & \multirow[b]{2}{*}{ Pereaksi } & \multicolumn{4}{|c|}{ Jenis Ekstrak } \\
\hline & & Air & Metanol & Etanol & Aseton \\
\hline Flavonoid & Bubuk $\mathrm{Mg} / \mathrm{HCl}$ & - & - & - & - \\
\hline Fenolik & Besi (III) klorida & + & + & + & + \\
\hline Saponin & Air/ $\mathrm{HCl}$ pekat & + & + & + & + \\
\hline Triterpenoid & Liebermann-Burchard & + & + & + & + \\
\hline Steroid & Liebermann-Burchard & - & - & - & - \\
\hline Alkaloid & Mayer & + & + & + & + \\
\hline Kumarin & $\mathrm{NaOH} 1 \%$ & - & - & - & - \\
\hline
\end{tabular}

Tabel 2. Pengaruh jenis pelarut terhadap hasil ekstraksi dan kandungan fenolik total

\begin{tabular}{lcc}
\hline \multicolumn{1}{r}{ Jenis Pelarut } & $\begin{array}{c}\text { Jumlah Ekstrak } \\
(\%)\end{array}$ & $\begin{array}{c}\text { Kandungan Fenolik Total } \\
(\mathrm{mg} \mathrm{GAE} / \mathrm{g})\end{array}$ \\
\hline Air & $12,75 \pm 0,32$ & $358,69 \pm 3,00$ \\
Metanol & & \\
$\quad$ Metanol 100\% & $17,72 \pm 0,58$ & $450,20 \pm 8,92$ \\
$\quad$ Metanol 75\% & $20,38 \pm 0,34$ & $426,01 \pm 4,93$ \\
$\quad$ Metanol 50\% & $21,51 \pm 0,40$ & $404,44 \pm 4,08$ \\
Etanol & & \\
$\quad$ Etanol 100\% & $11,05 \pm 0,45$ & $614,25 \pm 3,00$ \\
$\quad$ Etanol 75\% & $15,68 \pm 0,50$ & $499,87 \pm 4,93$ \\
$\quad$ Etanol 50\% & $18,39 \pm 0,63$ & $480,26 \pm 4,93$ \\
Aseton & & \\
$\quad$ Aseton 100\% & $9,20 \pm 0,52$ & $488,10 \pm 7,06$ \\
$\quad$ Aseton 75\% & $22,16 \pm 0,26$ & $487,45 \pm 5,88$ \\
$\quad$ Aseton 50\% & $34,98 \pm 0,15$ & $408,37 \pm 3,00$ \\
\hline
\end{tabular}




\section{Hasil Ekstraksi dan Kandungan Fenolik Total}

Hasil ekstraksi; pada penelitian ini ekstrak daun manggis diperoleh dengan menggunakan pelarut air, metanol, etanol, aseton dan pelarut air dengan perbandingan konsentrasi yang berbeda terhadap metanol, etanol, dan aseton (50\% dan 75\%). Pengaruh jenis pelarut terhadap hasil ekstraksi dan kandungan fenolik total dapat dilihat pada Tabel 2. Komposisi dari pelarut sangat mempengaruhi jumlah ekstrak dan kandungan fenolik total $(p<0,05)$.

Berdasarkan hasil dari kandungan fenolik total (Tabel 2), jumlah hasil ekstraksi berkisar antara 9,20\% untuk ekstrak aseton 100\% sampai dengan 34,98\% untuk ekstrak aseton 50\%. Hasil dari ekstraksi dengan berbagai pelarut menurun dengan urutan sebagai berikut: aseton $50 \%>$ aseton $75 \%>$ metanol $75 \%>$ metanol $75 \%>$ etanol $50 \%>$ metanol $100 \%>$ etanol $75 \%>$ air > etanol $100 \%>$ aseton $100 \%$. Dapat dilihat bahwa hasil ekstraksi metanol murni (17,72\%) lebih tinggi dibandingkan dengan etanol murni (11,05\%) dan aseton murni $(9,20 \%)$. Hal ini menunjukkan bahwa hasil ekstraksi meningkat dengan meningkatnya polaritas pelarut yang digunakan dalam ekstraksi. Hasil ekstrak menggunakan air lebih kecil dibandingkan metanol dikarenakan pelarut air hanya bisa melarutkan senyawa polar dalam sampel. Faktor yang mempengaruhi jumlah ekstrak pada proses ekstraksi adalah jumlah komponen aktif yang terdapat pada sampel, sifat dan kepolaran dari pelarut dan metoda ekstraksi yang digunakan [12]. Dalam pengujian menunjukkan bahwa peningkatan konsentrasi air dalam pelarut meningkatkan hasil ekstraksi. Ini disebabkan kelarutan yang lebih tinggi dari protein dan karbohidrat dalam air dan metanol dibandingkan dalam etanol dan aseton [13]. Penggunaan kombinasi air dan pelarut organik dapat meningkatkan ekstraksi bahan kimia yang larut dalam pelarut organik. Ini menjadi alasan mengapa hasil ektraksi metanol, etanol, dan aseton dengan penambahan air lebih tinggi dari hasil ekstrak air, metanol, etanol, dan aseton.
Kandungan Fenolik Total; pada Tabel 2 dapat dilihat nilai kandungan fenolik total dari ekstrak berkisar dari 358,69 mg GAE/g ekstrak daun manggis untuk ekstrak air hingga 614,25 mg GAE/g ektrak daun manggis untuk ekstrak etanol $100 \%$. Kandungan fenolik total pada ekstrak menurun dengan urutan pelarut sebagai berikut: etanol $100 \%>$ etanol $75 \%>$ aseton $100 \%>$ aseton $75 \%>$ etanol $50 \%>$ metanol $100 \%>$ metanol $75 \%>$ aseton $50 \%>$ metanol 50\% > air. Kandungan fenolik total dari ekstrak etanol 100\% lebih tinggi dari ekstrak aseton $100 \%$, sedangkan kandungan fenolik total dari ekstrak air secara signifikan lebih sedikit dibandingkan dengan pelarut lainnya. Ini disebabkan oleh kandungan karbohidrat dalam ekstrak air lebih banyak daripada ekstrak lainnya. Hal ini juga dapat disebabkan oleh kemungkinan pembentukan kompleks dari beberapa senyawa fenolik dalam ekstrak yang larut dalam metanol, aseton, dan etanol [14]. Berdasarkan hasil kandungan fenolik total, yang terbaik adalah pada pelarut etanol. Banyaknya senyawa fenolik yang terdapat pada masing-masing ekstrak memiliki pengaruh terhadap aktivitas antioksidan.

\section{Pengujian Aktivitas Antioksidan}

Masing-masing ekstrak dari sampel daun manggis diuji aktivitas antioksidannya dengan menggunakan metode DPPH dan pengukuran terhadap asam askorbat sebagai kontrol positif. Metode uji aktivitas antioksidan dengan DPPH (2,2-difenil-1-pikrilhidrazil) dipilih karena metode ini adalah metode sederhana, mudah, cepat dan peka serta hanya memerlukan sedikit sampel untuk evaluasi aktivitas antioksidan dari senyawa bahan alam sehingga digunakan secara luas untuk menguji kemampuan senyawa yang berperan sebagai pendonor electron [15]. Ekstrak daun manggis diuji dengan menggunakan variasi konsentrasi untuk melihat penghambatan (inhibisi) terhadap radikal bebas pada DPPH. Aktivitas scavenging radikal bebas dari ekstrak daun manggis diuji menggunakan metoda DPPH dan hasilnya dapat dilihat pada Gambar 1. 


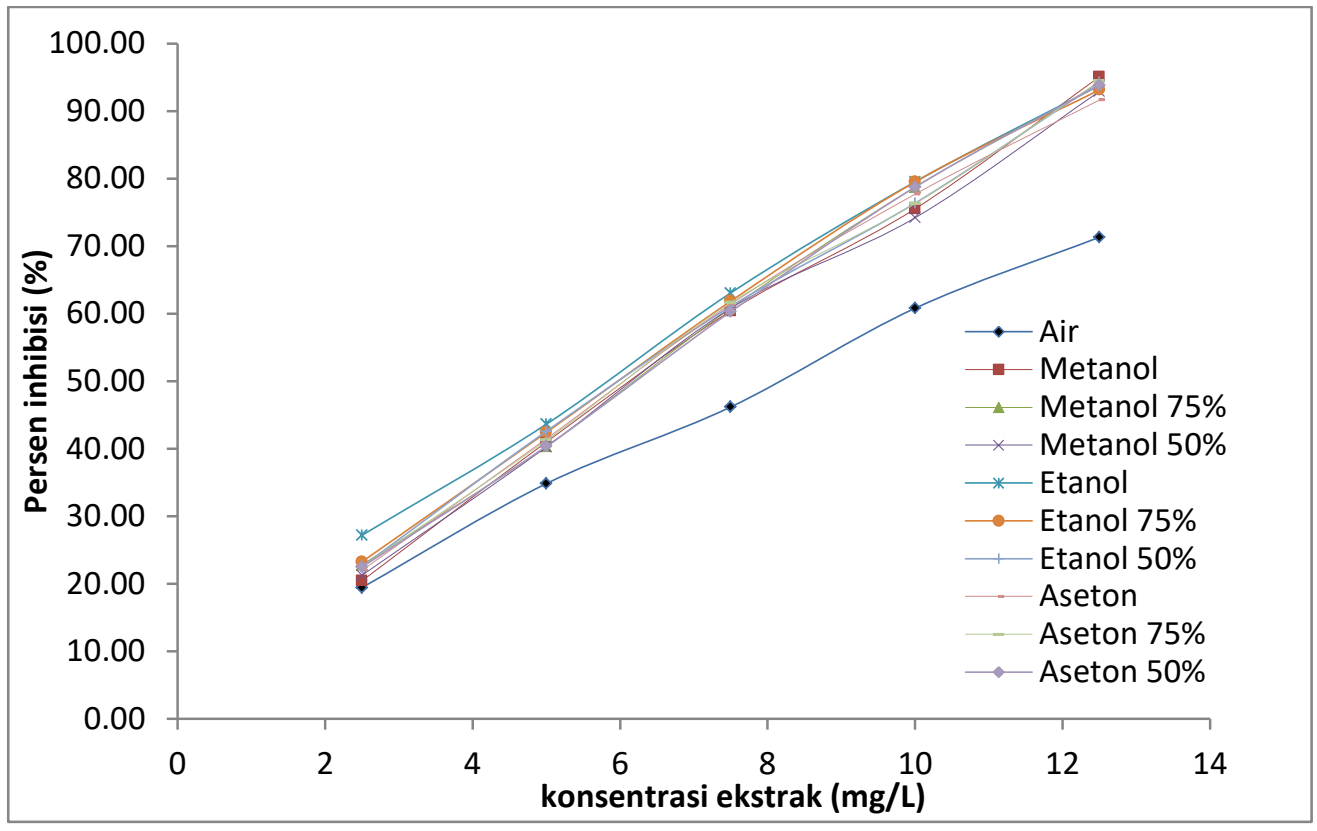

Gambar 1. Aktivitas scavenging radikal DPPH dari ekstrak daun manggis

Interaksi dari antioksidan tergantung pada sifat oksidasi dari radikal bebas. Antioksidan bereaksi dengan radikal bebas $\alpha, \alpha$-diphenyl- $\beta$ picrylhydrazyl (ungu pekat) dan merubahnya menjadi $\alpha, \alpha$-diphenyl- $\beta$-picrylhydrazine (kuning). Perubahan warna menunjukkan kemampuan penangkapan dari senyawa antioksidan, seperti senyawa fenolik ${ }^{[16]}$.

Gambar 1 menunjukkan aktivitas scavenging dari ekstrak daun manggis dengan berbagai jenis pelarut terhadap radikal DPPH. Ekstrak etanol $100 \%$ menghasilkan aktivitas scavenging radikal DPPH tertinggi pada rentang konsentrasi 2,5 mg/L hingga 12,5 mg/L. Pada penelitian ini, sifat antioksidan meningkat dari ekstrak etanol $100 \%$ > etanol $75 \%$ > etanol $50 \%$ > methanol $75 \%$ aseton $75 \%>$ aseton $100 \%$ aseton $50 \%>$ methanol $100 \%>$ methanol $50 \%$. Peningkatan sifat ini sesuai dengan peningkatan nilai kandungan fenolik total dari ekstrak. Nilai aktivitas peredaman radikal bebas yang dinyatakan dengan nilai $\mathrm{IC}_{50}$ (Inhibitory Concentration) didefinisikan sebagai besarnya konsentrasi senyawa uji yang dapat meredam radikal bebas sebanyak $50 \%$. Nilai IC50 masing-masing ekstrak daun manggis dapat dilihat pada Tabel 3.
Nilai IC50 dari suatu senyawa berbanding terbalik dengan kapasitas antioksidan, hal ini mengungkapkan jumlah antioksidan yang dibutuhkan untuk menurunkan konsentrasi $\mathrm{DPPH}$ sebesar $50 \%$, yang diperoleh dengan interpolasi dari analisis regresi linear [17]. Nilai IC 50 yang lebih rendah menunjukkan aktivitas antioksidan yang lebih tinggi dari senyawa sedangkan asam askorbat sebagai kontrol positif digunakan untuk membandingkan nilai $\mathrm{IC}_{50}$ dari ekstrak tersebut. Asam askorbat memiliki nilai $\mathrm{IC}_{50}$ yang tergolong sebagai antioksidan sangat aktif sehingga dapat dibandingkan dengan nilai konsentrasi inhibisi dari sampel yang digunakan. Hasil pengujian didapatkan nilai $\mathrm{IC}_{50}$ dari masing-masing ekstrak lebih rendah dari nilai $\mathrm{IC}_{50}$ asam askorbat. Ini membuktikan bahwa ekstrak daun manggis memiliki aktivitas antioksidan yang sangat aktif. Tabel 3 menunjukkan nilai $\mathrm{IC}_{50}$ dari masing-masing ekstrak. Ekstrak etanol $100 \%$ memiliki aktivitas radikal DPPH terkuat $\left(\mathrm{IC}_{50}=5,81 \mathrm{mg} / \mathrm{mL}\right)$. Aktivitas antioksidan tergolong kuat jika nilai $\mathrm{IC}_{50}$ kurang dari 50 $\mathrm{mg} / \mathrm{L}$, aktif jika nilai $\mathrm{IC}_{50} 50-100 \mathrm{mg} / \mathrm{L}$, sedang jika nilai IC 50 101-250 mg/L, lemah jika nilai IC 50 250-500 mg/L, dan tidak aktif jika nilai IC $_{50}$ lebih besar dari $500 \mathrm{mg} / \mathrm{L}{ }^{[17]}$. 
Tabel 3. Nilai konsentrasi inhibisi ( $\mathrm{IC}_{50}$ ) dari ekstrak daun manggis

\begin{tabular}{lc}
\hline \multicolumn{1}{c}{ Jenis Ekstrak } & IC $_{50}(\mathbf{m g} / \mathbf{L})$ \\
\hline Air & 8,17 \\
Metanol & \\
$\quad$ Metanol $100 \%$ & 6,34 \\
$\quad$ Metanol $75 \%$ & 6,21 \\
$\quad$ Metanol $50 \%$ & 6,38 \\
Etanol & \\
$\quad$ Etanol 100\% & 5,81 \\
$\quad$ Etanol $75 \%$ & 6,06 \\
$\quad$ Etanol 50\% & 6,19 \\
Aseton & \\
$\quad$ Aseton $100 \%$ & 6,24 \\
$\quad$ Aseton $75 \%$ & 6,21 \\
$\quad$ Aseton 50\% & 6,24 \\
Asam askorbat & 10,59 \\
\hline
\end{tabular}

\section{KESIMPULAN}

Berdasarkan hasil penelitian yang telah dilakukan terhadap daun manggis, dapat disimpulkan bahwa daun manggis positif mengandung senyawa fenolik, saponin, triterpenoid dan alkaloid. Secara umum, hasil ekstraksi meningkat dengan meningkatnya kadar air dalam metanol, etanol dan aseton. Jumlah ekstrak paling tinggi didapatkan dengan menggunakan pelarut aseton 50\% $(34,98 \pm 0,17)$. Ekstraksi menggunakan etanol 100\% menunjukkan jumlah kandungan fenolik total tertinggi $(614,25 \pm 5,58 \mathrm{mg} \mathrm{GAE} / \mathrm{g}$ ekstrak) dan nilai terendah dari $\mathrm{IC}_{50}(5,81 \mathrm{mg} / \mathrm{L})$. Hasil penelitian ini menunjukkan bahwa pelarut aseton 50\% dapat memaksimalkan jumlah hasil ekstraksi dan etanol $100 \%$ dapat memaksimalkan jumlah ekstrak, kandungan senyawa fenolik total dan aktivitas antioksidan dari daun manggis.

\section{DAFTAR PUSTAKA}

1. Pedraza-Chaverri, J, Cárdenas-Rodríguez, N, Orozco-Ibarra, M. \& Pérez-Rojas, J. M., Medicinal properties of mangosteen (Garcinia mangostana), Food Chem. Toxicol., 46 (10): 3227 - 3239 (2008).

2. Witantri, R. G., Ruspendi, E. C. A. \& Saputro, D. S., Keanekaragaman Pohon
Berpotensi Obat Antikanker di Kawasan Kampus Kentingan Universitas Sebelas Maret, Surakarta, Jawa Tengah. Pros Sem Nas Masy Biodiv Indon UNS. 1(2): 477 - 483 (2015).

3. Mardawati, Filiantiy F. \& Marta, H., Jurnal Kajian Aktivitas Antioksidan Ekstrak Kulit Manggis (Garcinia Mangostana Linn.) dalam Rangka Pemanfaatan Limbah Kulit Manggis di Kecamatan Puspahiang Kabupaten Tasikmalaya, Bandung: Universitas Padjajaran (2011).

4. Amar, Uji Aktivitas Antioksidan Ekstrak Etanol Daun Manggis dengan Metode DPPH ,Ilmiah Farmasi, Universitas Muhammadiyah Purwokerto (2014).

5. Nursal, S., Wulandari, S. \& Syahputra, B., Uji Toksisitas Ekstrak Etanol Kulit Batang Rengas (Gluta renghas) terhadap Larva Udang Artemia salina, Jurnal Biogenesis. 13(1): 11 - 18 (2016).

6. Harborne, J. D., Metode Fitokimia Penuntun Cara Modern Menganalisis Tumbuhan. ITB, Bandung (1987).

7. Hakim, D. R., Isolasi dan Uji toksisitas Senyawa Alkaloid dari Kulit Batang Tumbuhan Polyalthia rumphii (B) Merr. (Annonaceae). Skripsi. Program Studi Kimia FMIPA UR (2014). 
8. Purnama, R. Aktivitas antioksidan, kandungan total fenol, dan flavonoid lima tanaman hutan yang berpotensi sebagai obat alami. Skripsi. Institut Pertanian Bogor, Bogor (2015).

9. Aranda, R., Lopez, L., Arroyo, J., Garza, B. \& Torres, N., Antimicrobial and antioxidant activities of plants from Northeast of Mexico. Evid. Based Complement Alternat. Med., 15: 1-7 (2011).

10. Ekawati, Minanti A., Isolasi dan Identifikasi Senyawa Flavonoid pada Daun Sembukan (Paederia foetida L) serta Uji Aktivitasnya Sebagai Antioksidan. Jurnal Kimia. Jurusan Kimia FMIPA Universitas Udayana, Bukit Jimbaran: Bali. 11(1): 43-48 (2017).

11. Zuraida, Sulistiyani, Sajuthi, Dondin, Suparto \& Irma Herawati. Fenol, Flavonoid, dan Aktivitas Antioksidan pada Ekstrak Kulit Batang Pulai (Alstonia scholaris R.Br). JPHH, 35(3): (2017).

12. Naji Alsultan, Q. M., Sijam, K., Rashid, T., Ahmad, K. \& Awla, H., Investigation of phytochemical components and bioautography of Garcinia mangostana L.
Methanol Leaf Extract. JEAI, 15(3): 1-7 (2017).

13. Wijekoon M. M. J. O., Bhat R. \& Karim A. A., Effect of extraction solvents on the phenolic compounds and antioxidant activities of bunga kantan (Etlingera elatior Jack.) in florescence. J. Food Compos. Anal., 24: 615-619 (2011).

14. Pinelo M., Manzocco L., Nunez M. J. \& Nicoli C., Interaction among phenols in food fortification: negative synergism on antioxidant capacity. J. Agric. Food Chem., 52(5): 1177-1180 (2004).

15. Dhruti, M., Bhavika, P. \& Meonis, P., Studies on Phytochemical constituents and antioxidant activity of Alstonia scholaris, IJLSCI, 4(4): 529-538 (2016).

16. Amzad Hossain, M. \& Shah, M. D., A study on the total phenols content and antioxidant activity of essential oil and different solvent extracts of endemic plant Merremia borneensis, Arab. J. Chem., 8(1): 6671 (2015).

17. Putri, A. A. S. \& Hidajati, N., Uji Aktivitas Antioksidan Senyawa Fenolik Ekstrak Metanol Kulit Batang Tumbuhan Nyiri Batu (Xylocarpus moluccensis). UNESA Journal of Chemistry. 4(1): 37-42 (2015). 